\title{
The opportunity cost of parking requirements: Would Silicon Valley be richer if its parking requirements were lower?
}

\author{
C.J. Gabbe (corresponding author) \\ Santa Clara University \\ cgabbe@scu.edu
}

\author{
Taner Osman \\ University of California, Los Angeles \\ tanerosman@ucla.edu
}

\author{
Michael Manville \\ University of California, Los Angeles \\ mmanvill@g.ucla.edu
}

\begin{abstract}
We estimate the off-street parking supply of the seven most economically productive cities in Santa Clara County, California, better known as Silicon Valley. Using assessor data, municipal zoning data, and visual inspection of aerial imagery, we estimate that about 13 percent of the land area in these cities is devoted to parking, and that more than half of the average commercial parcel is parking space. This latter fact suggests that minimum parking requirements, if binding, depress Silicon Valley's commercial and industrial densities, and thus its economic output. In an exploratory empirical exercise, we simulate a reduction in parking requirements from the year 2000 forward and show that under conservative assumptions the region could have added space for nearly 13,000 jobs, equivalent to a 37 percent increase over the actual job growth that occurred during that time. These additional jobs would be disproportionately located in the region's highest-wage zip codes and could add more than $\$ 1$ billion in payroll annually, further implying a large productivity gain.
\end{abstract}

\section{Article history:}

Received: March 13, 2020

Received in revised form: August 7, 2020

Accepted: October 7, 2020

Available online: February 22,

2021

\section{Introduction}

A canonical finding in urban economics is that productivity moves in sync with density. This finding, moreover, holds almost regardless of how productivity is measured. Wages, rents, patents, and regional product per capita are all higher in places where people and firms are more tightly clustered (Ahlfeldt $\&$ Pietrostefani, 2019; Carlino, Chatterjee, \& Hunt, 2007; Glaeser \& Kahn, 2001; Graham, 2007; Harris $\&$ Ioannides, 2000). The relationship between productivity and density also appears to hold within regions. The densest areas of productive regions are themselves disproportionately productive. New York is more productive than Orlando, and Manhattan is more productive than New York. Clustering also boosts economic output at the neighborhood scale (Andersson, Klaesson, \& Larsson, 2016; Arzaghi \& Henderson, 2008; Melo, Graham, \& Noland, 2009; Rosenthal \& Strange, 2003, 2010).

These stylized facts, well-accepted as they are, also suggest that an anomaly sits atop America's productivity heap: Silicon Valley. Ranking large US urban areas by their productivity (measured as regional GDP per capita) yields a list that reads, for the most part, like a catalog of central city density:

Copyright 2021 C.J. Gabbe, Michael Manville \& Taner Osman

http://dx.doi.org/10.5198/jtlu.2021.1758

ISSN: 1938-7849 | Licensed under the Creative Commons Attribution - Noncommercial License 4.0

The Journal of Transport and Land Use is the official journal of the World Society for Transport and Land Use (WSTLUR) and is published and sponsored by the University of Minnesota Center for Transportation Studies. 
San Francisco, Seattle, Boston, New York. All of these places, however, are less productive than Silicon Valley. And while Silicon Valley is dense compared to the average US metropolitan area, it is much less dense, especially in its center, than its productive peers. Silicon Valley is part of a triumvirate of regions, along with New York and San Francisco, that Hsieh and Moretti (2019) identify as disproportionate engines of American growth. Yet Silicon Valley, which we - following convention - define as Santa Clara County, stands out within that club of growth for being less centralized, less dense, and more productive. ${ }^{1}$

Two main factors explain Silicon Valley's low density. The first, which is not the focus of this paper, is the region's sheer prevalence of detached single-family homes, and its relative absence of taller multifamily structures. The second, which is the focus of this paper, is the inordinate share of the Valley's commercial and industrial land that is devoted to parking.

Parking is not a productive land use. Parking can complement productive land uses (if, for instance, buildings with jobs can be accessed only by car) but land used for parking tends not by itself to generate income or employment. For this reason, parking is most prevalent where land values are lower. It is scarce in the heart of New York, London or Tokyo, more common in their outlying suburbs, and plentiful in economically troubled urban centers that struggle with decline. Buffalo, Cleveland and Rochester have large swathes of land with few economically viable uses. The owners of this land convert it to vehicle storage, which earns little money but also costs little to operate. The result is what urbanists call "parking craters"- voids in the urban fabric created by parking lots (e.g., Schmitt, 2013).

Silicon Valley is assuredly not in decline, and it does not have vast swathes of land with no plausible economic use. To the contrary, it is an economic juggernaut, and its land ranks among the most valuable on earth. In its parking provision, however, it looks more like a suburb, or a declining city. We argue that this anomaly arises because Silicon Valley's cities have high minimum off-street parking requirements. These parking requirements impose low-value uses on high-value land. This imposition, in turn, implies a large opportunity cost. A Silicon Valley with lower parking requirements might have less parking, and less parking could enable more clustering of firms and workers. More clustering could make the region more productive, and increase the region's output. Local parking requirements could thus be restraining one of the world's most dynamic urban economies. That is the idea we examine here.

Our contribution is twofold. First, we estimate the parking inventory of Silicon Valley's most productive cities. Second, we use this estimate to generate a counterfactual scenario: what if these cities had reduced their parking requirements in the year 2000? While we examine all parcels in these cities, for both conceptual and practical reasons we pay particular attention to office parcels. The conceptual reason springs from the important role of office-oriented development in Silicon Valley's economy; given the transition of the region's IT industry from manufacturing to knowledge-based activities, what happens on office parcels arguably drives the region's output. The practical reason is that office parcels, as we discuss below, may offer the most reliable window into the region's parking provision.

Applying some baseline assumptions about increased density, as well as reasonable elasticities of employment and wages to density, we find that a Silicon Valley with lower parking requirements could have accommodated 12,886 additional jobs, which would have been 37 percent higher than what actually occurred over the period 2000-2016. The greater job density of this counterfactual urban form would have been associated with not just higher levels of productivity but environmental and social equity benefits as well.

\footnotetext{
${ }^{1}$ For more detail on defining Silicon Valley, see Osman (2020).
} 
The paper's next section introduces Silicon Valley's unusual position in the hierarchy of American productivity. Section III then discusses some relevant literature from urban economics and land use, and in Section IV we lay out our methodological approach. Section V presents our results, and Section VI concludes.

\section{Silicon Valley: Urban economy, suburban zoning}

Table 1 illustrates Silicon Valley's exceptionalism and begins our examination of what explains it. The table compares the San Jose/Santa Clara metropolitan statistical area (MSA) to the MSAs of New York, San Francisco and Boston. All four are economically dynamic. As context, in 2017, across 381 US MSAs, average per capita regional product was $\$ 42,530$. Table 1's first row therefore shows that New York's regional product is 66 percent higher than the US average, Boston's is 81 percent higher, and San Francisco's is over 100 percent higher. Even among this group, however, Santa Clara sits in a class by itself. Its regional product, at just under $\$ 120,000$ per capita, is well above San Francisco's and almost triple the national average.

Table 1. Density and productivity, four metropolitan areas (2017)

\begin{tabular}{|c|c|c|c|c|}
\hline & Santa Clara & San Francisco & New York & Boston \\
\hline GDP per capita & $\$ 119,736$ & $\$ 87,536$ & $\$ 70,314$ & $\$ 76,831$ \\
\hline Center city population share & $52 \%$ & $19 \%$ & $63 \%$ & $14 \%$ \\
\hline \multicolumn{5}{|l|}{ Jobs per square mile } \\
\hline Region & 372 & 837 & 1,195 & 673 \\
\hline Center city & 2,015 & 13,435 & 7,317 & 9,556 \\
\hline \multicolumn{5}{|l|}{ Establishments per square mile } \\
\hline Region & 37 & 65 & 250 & 37 \\
\hline Center city & 114 & 732 & 790 & 385 \\
\hline \multicolumn{5}{|l|}{ Population per square mile } \\
\hline Region & 728 & 1,867 & 2,429 & 1,375 \\
\hline Center city & 5,800 & 19,000 & 28,000 & 13,937 \\
\hline \multicolumn{5}{|c|}{ Share of housing detached single family } \\
\hline Region & $53 \%$ & $50 \%$ & $37 \%$ & $48 \%$ \\
\hline Center city & $53 \%$ & $20 \%$ & $9 \%$ & $11 \%$ \\
\hline \multicolumn{5}{|c|}{ Share of housing w/garage or carport } \\
\hline Region & $89 \%$ & $79 \%$ & $45 \%$ & $43 \%$ \\
\hline Center city & $91 \%$ & $70 \%$ & $22 \%$ & $30 \%$ \\
\hline
\end{tabular}

Sources: US BEA, US BLS, American Community Survey, American Housing Survey (2017). Quarterly Census of Employment and Wages.

Note: Parking includes all MSA center cities, does not include off-street spaces that are not garage or carport

The puzzle begins in the table's subsequent rows. Compared to the other MSAs, Santa Clara hasboth regionally but especially in its center city of San Jose-far less clustering of people and firms. The Santa Clara MSA's population density is less than half that of San Francisco and one third that of New York. Its business establishment density is less than half San Francisco's and one-seventh New York's. Boston's employment density is almost double Santa Clara's, and employment density in San Francisco 
and New York is more than double Santa Clara's. These differences are magnified, moreover, when we examine each MSA's center city. On measures of population density, employment density, and establishment density, San Jose lags. Boston's employment density is almost five times San Jose's. San Francisco's is over six times San Jose's.

On their face, these statistics suggest tremendous inefficiency. Silicon Valley is far more productive than Boston, New York or San Francisco, yet uses its land much less intensively. Land is the defining factor of any urban economy: it is the fixed and immobile resource on which labor and capital are mixed. Failing to use that land intensively implies productivity lost.

\subsection{Explaining Silicon Valley's low-density land uses}

Table 1's bottom portion suggests two reasons for the Valley's low land-use intensity, both of which we mentioned in the introduction. The first is the region's preponderance of detached single-family homes. Over half the housing units in Santa Clara are detached single-family homes. This proportion is higher than in other MSAs, but not dramatically so. In Boston and San Francisco about half of all housing is detached single-family, while in New York the figure is 37 percent. Notably, however, in Silicon Valley this tendency toward single-family living does not diminish in the center city. San Jose's proportion of housing units in detached single-family homes is almost identical to the proportion in Silicon Valley overall. By way of comparison, in the center cities of the San Francisco, Boston and New York MSAs only 20, 11 and 9 percent of housing units are detached single-family homes, respectively.

Second is the inordinate share of land the Valley devotes to parking. At this point we have no direct way to quantify the Valley's parking, because parking inventories, and especially nonresidential parking inventories, are not tracked in any national, state, or local statistics-a fact that motivates the first part of our empirical exercise below. ${ }^{2}$ So for the moment we must use some proxies. Table 1's last rows are drawn from the American Housing Survey (AHS), which tracks the share of housing units that include a garage or carport in their rent or purchase price. To the extent such bundled parking is an indicator of parking's abundance overall, these figures suggest parking is much more common in Silicon Valley. Almost 90 percent of housing units in San Jose come with parking, compared to 70 percent in San Francisco and less than 30 percent in Boston and New York. These figures, moreover, may well understate the difference. The AHS only tracks housing units, and only records whether a unit has parking included or not. It does not say how many spaces each unit has. The prevalence of detached single-family homes in Silicon Valley, which often feature driveways and garages, suggest that the typical Silicon Valley housing unit may not be just more likely to have parking, but more likely to have more parking.

Residential parking, of course, cannot directly explain a low density of jobs or firms. Nevertheless, we have reason to think that compared to other productive regions, Silicon Valley devotes far more nonresidential land to parking. Figure 1 shows aerial imagery, from Google Maps, of the tallest commercial buildings in San Francisco (the 61-story, 305-meter Salesforce Tower), San Jose (the 19-story, 87-meter Sobrato Office Tower) and Detroit (the 73-story, 222-meter Marriott hotel at General Motors' Renaissance Center complex). The disparity in land use intensity between San Francisco and San Jose, and the role parking plays in that disparity, is pronounced. ${ }^{3}$ Salesforce is one of many towers in its neighborhood, and no parking is visible. The Sobrato, in contrast, is a lonely tall building that sits on a parking podium and is surrounded by surface parking on all sides. Perhaps more startling, from the air the Sobrato Tower and its landscape more closely resemble Detroit, a city far distant from San Jose in

${ }^{2}$ There is also little data on how intensively these parking spaces are used. We do not focus on use because as an indicator of parking's value it is endogenous to provision. If enough parking is provided, and its price falls as a result, people will use it. 3 Some parts of San Jose's downtown sit in a flight path to Mineta San Jose International Airport, which leads to lower building height regulations (City of San Jose, 2013; San Jose Mercury News, 2019). 
both geography and economic fortune, than San Francisco. San Francisco is 80 kilometers (50 miles) from San Jose and has an overlapping high-tech industrial base. Detroit is thousands of kilometers away and the n'est plus ultra of urban decline. Its per capita regional product is 60 percent lower than Santa Clara's, and its central city, is renowned for vacant housing and surplus land.
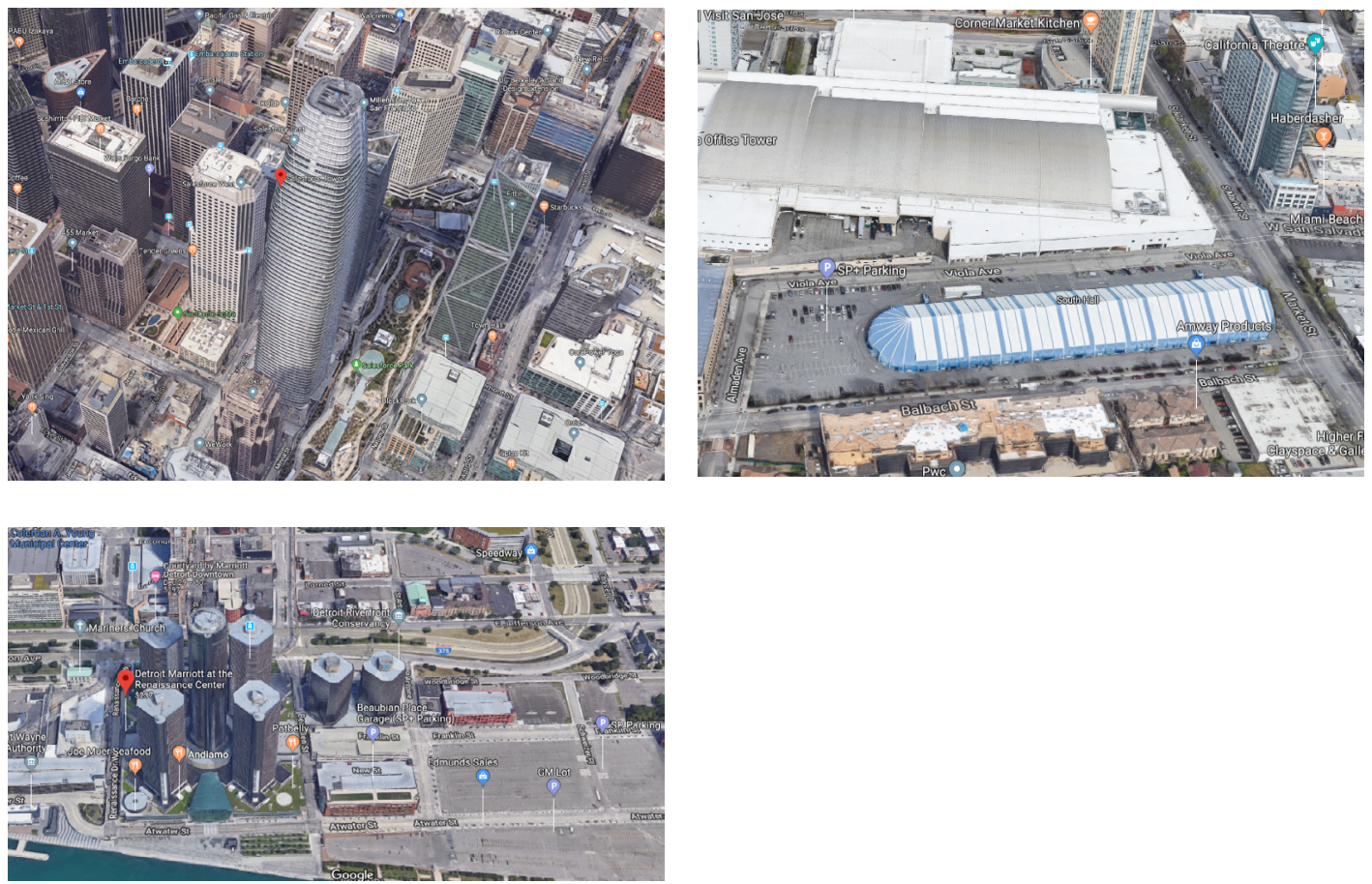

Figure 1. Imagery of downtown San Francisco (top left), San Jose (top right), and Detroit (bottom left) from Google Maps

\subsection{Comparing parking policies across metropolitan areas}

Silicon Valley is not Detroit, and decline cannot explain its parking landscape. Zoning, however, can. Compared to Boston, New York and San Francisco, the cities of Silicon Valley have minimum parking requirements that are not just higher but also apply to a greater share of buildings, especially in the central city. The densest parts of New York, San Francisco and Boston have large areas where the government imposes parking maximums - limiting rather than mandating the supply of parking (Shoup 2011; Manville et al., 2013). Boston's downtown commercial parking freeze began in 1976, and neighboring Cambridge began restricting parking in 1980. New York began enforcing parking maximums in Manhattan in 1981. San Francisco began enforcing parking maximums in the 1990s and expanded them in 2007. No city in Santa Clara County, in contrast, has ever enforced a parking maximum. Parking minimums there, as we describe below, are long-standing, high, and ubiquitous.

New York, San Francisco and Boston also have older built environments than Silicon Valley, meaning they have more structures that predate parking requirements. Systematic data on the age of commercial and industrial structures by MSA is not readily available in the United States, but what evidence exists suggests that almost all of Silicon Valley's growth occurred in the postwar era. Only 6 percent of San Jose's housing predates 1940, and 80 percent was built between 1940 and 2000. Half of Boston city's housing, in contrast, predates 1940.

Most of Silicon Valley's nonresidential structures, similarly, were built after World War II. Our cal- 
culations from assessor data (described more below) show that only about 2 percent of San Jose's office space, and 2.4 percent of its manufacturing space, was built before 1940. Nonresidential space in the central cities of New York, Boston and San Francisco tend to be much older. In 2010, for example, CB Richard Ellis estimated that the average large office building in midtown Manhattan was 57 years old, in downtown Manhattan 67 years old, and in Midtown South 92 years old-meaning many office buildings predate the city's 1961 zoning reform that introduced minimum parking requirements ( $\mathrm{Li}, 2010)$.

Alone among the nation's powerhouse MSAs, then, Santa Clara County is dominated, even in its center city, by the physical and regulatory landscape of the automobile. It is a region with the economy of a megacity but the zoning of a suburb. A priori, this should exact a toll on its output.

\section{Parking, proximity, and agglomeration}

To examine the potential relationship between parking requirements and productivity, we draw on the academic literature related to agglomeration economies (Ahlfeldt \& Pietrostefani, 2019; Duranton \& Puga, 2004; Glaeser, 1998; Rosenthal \& Strange, 2003; Storper, 1997), as well as the related literatures on factor misallocation and land use (Hsieh \& Moretti, 2019), the distortionary effects of land use regulation (Glaeser \& Gyourko, 2003), and the measurement and impacts of parking provision and regulation (Chester, Fraser, Matute, Flower, \& Pendyala, 2015; Shoup, 2011).

\subsection{Agglomeration economies}

The idea that economies thrive on proximity isn't new. Marshall (1890) first argued that when firms of the same industry clustered, three advantages accrued: sharing, matching, and learning. Density lets firms share inputs, and allows the formation of other, specialized firms that supply those inputs- not just law firms, for example, but law firms that focused on software patenting (sharing). Density also lets employers and workers find each other more efficiently, reducing labor market frictions (matching). Perhaps most important, clustering allowed information, and particularly the tacit knowledge that feeds innovation, to flow more easily (learning).

Since Marshall's day, scholars have further observed that density can reduce transaction costs (Ogawa \& Fujita, 1980). All else equal, the cost of two firms conducting business grows with the physical distance between them. Technology can mitigate these costs, and let some transactions occur virtually. Yet even in an age where transportation and communication costs are low, important transactions seem to demand face-to-face contact (Leamer \& Storper, 2001). Proximity still matters, and at least some evidence, suggests that it may be more important in Silicon Valley-style high-tech service work (Graham, Melo, Jiwattanakulpaisarn, \& Noland, 2010).

The productivity returns from proximity manifest in different ways, with the most prominent being a wage premium associated with urban density. Scholars have by now documented this density-wage premium extensively, although estimates of its magnitude vary, and sometimes vary substantially, often depending on the sample of regions used. In the US, Glaeser and Kahn (2004) find that as metropolitan-level density increases by 10 percent, wages increase around 1.3 percent. Some other estimates put the premium much lower (Ahlfeldt \& Pietrostefani 2019), while a host of other studies find ranges similar to Glaeser and Kahn (Combes, Duranton, Gobillon, 2008, 2012; Andersson et al., 2016).

These figures are all metropolitan estimates: they refer to wage premiums associated with the average density of jobs or people across entire regions. Regionwide average density, however, can conceal substantial and meaningful variations within that region. There is reason to think, however, that density within regions also matters, and that regionwide average density can conceal substantial and meaningful 
intra-regional variation.

Andersson et al. (2016) show that the wage premium associated with job density is twice as high at the neighborhood as the city-level. Other evidence suggests that the benefits of firm proximity begin to diminish at a distance of as little as a quarter of a mile, (Arzaghi \& Henderson, 2008; Rosenthal \& Strange, 2003). It helps, in short, for firms to be very close together.

These close-quarters intraregional effects probably arise from knowledge spillovers. The Marshallian agglomeration mechanisms (sharing, matching and learning) likely function at different spatial sales (Rosenthal \& Strange, 2004). Sharing and matching tend to be regional: suppliers need to be near but not atop their clients, and employers and employees can find each other over relatively long distances (e.g., firms in central business districts will hire people who live in the suburbs). But knowledge dissipates quickly. Securities firms on Wall Street may acquire more industry information than similar firms in New Jersey. Informal flows of knowledge within and across firms decay sharply with distance (Duranton \& Puga, 2015; Lucas \& Rossi-Hansberg, 2002).

Density also has disadvantages, of course, and its benefits must be weighed against those costs. Clustering can benefit firms within the cluster, but demand to be in the cluster means land prices and congestion increase, which means firms closer to the agglomeration's heart must pay higher rents, and compensate their workers for higher housing costs or longer commutes (Duranton \& Puga, 2015; Ogawa \& Fujita, 1980). Some firms, when confronted with these costs, will choose to locate farther out. They will reduce the benefits they get from the agglomeration, but also lower their costs.

What all this suggests, in theory, is that firms should cluster until the costs of more density offset the benefits. Each firm will reach this point, and in a regional general equilibrium each firm will be optimally located, according to its own cost-benefit analysis, with respect to these factors. City-level productivity thus becomes the sum of these localized density effects.

This logic assumes, however, that regulations allow such optimization across space to occur. They may not. If regulation limits land use intensity in productive places, then firms and workers might cluster less than is socially optimal. Regulation could restrict intensity if it increases housing costs, and prevents workers from moving to an agglomeration, thereby making a region artificially under-sized (Ganong \& Shoag 2017; Hsieh \& Moretti, 2019), or if it pushes firms in a region inefficiently apart in space, thereby reducing the density of an agglomeration of any size. In either of these scenarios, productivity could fall.

\subsection{The effects of parking requirements on density and productivity}

Regulations take many forms. In the planning and land use literature, residential zoning gets the most attention. Residential zoning, however, can have only an indirect (albeit potentially large) impact on firm agglomeration. Low density residential zoning can inhibit the supply of labor but does not directly influence how firms themselves are spatially organized. Firms locate on commercial, industrial and mixed-use parcels, not residential parcels.

Parking requirements, in contrast, could directly impact firm density; they fall on commercial, industrial and mixed-use parcels, and ample evidence suggests that they can inhibit density on such parcels (Cutter \& Franco, 2012; Manville, Beata, \& Shoup, 2013; Manville \& Shoup, 2005; Shoup, 2011). Supplying parking is either land intensive (for surface parking) or capital intensive (for structured or subterranean parking). In either case parking consumes resources that developers could have otherwise used to create job- and income-producing space.

Parking requirements will only have this adverse effect if they bind-if they force developers to provide more parking than they otherwise would. Many developments will voluntarily provide at least 
some of parking, because parking is not just a cost. Parking provides an obvious benefit to people who drive, meaning that in automobile-oriented regions it allows access to income-generating space. By this logic, parking could facilitate, not just inhibit, agglomeration.

What matters, then, is whether the marginal parking space is a product only of zoning. If a developer believes the next space she provides would increase access to the building — and thus increase the building's value - by more than it reduces the building's income potential (by diverting space or money from additional rentable area), she will build that space. If she does not believe as much, then she only builds that space if the zoning mandates it. One way to calculate the regionwide cost of the parking requirement, therefore, is to sum all the parking spaces whose private costs exceeds their private returns - all the spaces that would not exist but for the zoning. As we discuss in the next section, this is essentially how we measure parking's social cost.

Before proceeding, however, we should note that this estimate could be conservative, and thus understate parking's ability to inhibit agglomeration. Developers worry about private returns on their own parcels. Agglomeration, however, yields social returns: it is a collective good that arises when many firms cluster near each other. Individual developers consider (and pay for) their own benefits from this clustering, but probably discount the benefits their location delivers to others, and may in fact try to free ride off the agglomeration itself. To illustrate, consider a cluster of buildings whose density is enabled in part by the absence of parking requirements. A developer constructing the cluster's next building would benefit from the density nearby, but might find it profitable to build slightly more parking precisely because parking is scarce; doing so would let him offer tenants not just access to the cluster but also easier access by driving, which could yield higher rent. In choosing to provide parking rather than productive space, the developer contributes less to the agglomeration he is joining and benefiting from. ${ }^{4}$ To the extent this sort of free riding occurs, some parking spaces with net private benefits will also have net social costs, and estimates of parking's costs based only on a developer's calculus will understate the social cost of parking.

All these computations also leave aside parking's well-known collective costs related to transportation. A landscape laden with off-street parking is one that encourages motor vehicle ownership and use (Manville, 2017; Manville \& Pinski, 2020), and one that discourages walking, cycling, and transit use. Thus even parking spaces that facilitate agglomeration carry some social costs, if that same agglomeration could have been facilitated in a less resource-intensive way.

\section{$4 \quad$ Measurement and empirical approach}

Our goal is to estimate the off-street parking inventory of the major cities in Silicon Valley, and then estimate the productivity costs associated with that parking. Doing so requires us to estimate the number of parking spaces, determine if those spaces are the result of binding regulation, and then generate a reasonable counterfactual: if the Valley had less parking, would employment, wages, or other measures of productivity be higher?

We emphasize- and will reiterate- that this entire exercise relies on, and is sensitive to, some strong assumptions. Most of these assumptions arise from the empirical challenge of estimating the parking inventory. In the United States, systematic data on parking, and especially private off-street parking, are essentially nonexistent.

\footnotetext{
${ }^{4}$ Still more strategically, some firms may want to manipulate their workers' exposure to an agglomeration. They may try to soak up the embodied knowledge in the region, but keep their own knowledge secret and minimize attempts from competitors to poach their workers. Large parking lots might be one way to secure such a competitive advantage, but the urban locations like Amazon, Twitter, Salesforce, Uber, and Dropbox suggest they may not be a necessary condition.
} 
As a consequence, a recurring obstacle in the parking literature is generating accurate counts of parking supply. At smaller geographic scales, researchers can overcome this problem with aerial photography and on-site surveys (Akbari, Shea Rose, \& Taha, 2003; City of Oakland/MTC, 2016; Fort Hill Infrastructure Services, 2017; Manville, 2013; McCahill \& Garrick, 2012; Weinberger, Seaman, \& Johnson, 2009). Even in the best circumstances, however, these methods are time- and resourceintensive, and often yield incomplete estimates. Not all properties respond to surveys, and municipal parking censuses often cannot count spaces in private garages. Aerial photos can miss or undercount covered or subterranean parking.

At the regional scale, all these approaches become virtually impossible. Researchers trying to estimate regional parking inventories must therefore infer them from secondary data. The quality and availability of such secondary data, however, varies greatly. One obvious source is cadastral (assessor) data, but property assessment records differ across places, and many do not record parking inventories. Scharnhorst et al. (2018), for example, used assessor data to inventory off-street parking in five cities (Jackson, Des Moines, Seattle, Philadelphia, New York). Their project had to use slightly different methods for each city, because assessor data was inconsistent from place to place.

Chester et al. (2015) and Hoehne, Chester, Fraser, and King (2019) estimate parking inventories in LA County and Metro Phoenix, respectively, using a combination of parking requirements, assessor data, and a model of building construction and turnover. To simplify greatly, these articles first estimate when a parcel was developed, and then assume that the parking associated with that development roughly conforms to the parking requirement on the books for that parcel at that time. From there they generate parking counts. Chester et al. (2015) use this method, along with a second approach for counting on-street spaces, to conclude that in 2010 Los Angeles County had 18.6 million parking spaces. Of these, 3.6 million were on-street, meaning there were 15 million off-street spaces, of which 9.6 million were nonresidential. This 18.6 million space estimate works out to 3.3 spaces per vehicle, or about $14 \%$ of the county's incorporated land area. Hoehne et al. (2019), similarly, find that there are over 12 million parking spaces in Metro Phoenix, or 3 spaces per person. For every personal auto there are 4.3 spaces, and-similar to Los Angeles - there are more off-street than on-street spaces (the region has 2.6 off-street spaces per person, and 1.7 on-street spaces per person).

\subsection{Estimate existing parking inventory}

Our own approach is as follows. We first secured data from the Santa Clara County assessor's office. Because our interest is in the relationship between parking requirements and firms, as a first step we restrict our analysis to the seven largest Valley cities, which hold the vast majority of the region's jobs and economic activity. These cities are San Jose, Sunnyvale, Santa Clara (city), Mountain View, Milpitas, Palo Alto, and Cupertino. We then, within those seven cities, drop any residential parcels with fewer than five units of housing. We do so because the vast majority of these smaller-scale housing parcels are detached single-family homes, and are located in areas where zoning only allows detached single-family homes. While these homes do provide plentiful parking, the binding constraint to development in these areas is not the parking requirement but the R1 restriction - the blanket prohibition of any other type of structure. Changing parking requirements on these parcels would not change their development density, nor the number or distribution of firms or workers. We also drop parcels reserved for transportation, agriculture, open space, cemeteries and mortuaries, recreation and golf, open space, and landfills.

These adjustments leave us with a sample of 19,209 parcels, representing all commercial, industrial and multifamily residential land in the seven cities. Our next step is estimating parking provision. Here we encounter a problem: the assessor dataset appears unreliable in several respects, parking among them. 
The dataset has some missing values in key fields, and some of the values that are present are inconsistent with each other. For example, rentable square footage (one portion of a building) is sometimes larger than the total square footage (the entirety of a building). Similarly, buildings listed as having rentable area are sometimes also listed as having zero floors, which seems impossible.

The biggest problem, however, is that the assessor's parking data seem inaccurate. While the dataset included some fields with parking counts, these fields were mostly empty, and our own checks using aerial imagery suggested that many of the non-missing parking counts were wrong. Rather than rely on those data, our method instead was the following: for each parcel, we estimated the building footprint (by dividing total building area by number of stories) and then subtracted that estimated footprint from the parcel area. This leaves us with the parcel's non-building area.

We assume, probably conservatively, that $70 \%$ percent of the non-building area is either parking or areas devoted to parking (e.g. driveways, ramps), while the remainder is landscaping, green space or other non-building uses. ${ }^{5}$ Having estimated this parking area, we can then calculate the share of each parcel devoted to parking, and generate an estimated count of parking spaces. We generate the count by assuming, following convention, that an off-street parking space requires approximately 27.9 square meters (300 square feet), once driveways and lanes between rows of spaces are accounted for (Shoup, 2011).

Our method is imperfect. Our estimates could be biased a parcel is very heavily or lightly landscaped (e.g., if 5 or 50 percent of non-building area is green space, rather than 30 percent); if a building is heavily stepped back with each additional floor, which would confound our estimate of the building's footprint; if the parking is structured, underground or otherwise covered; if the parcel is largely vacant; or if the parcel is a heavily car-oriented--for instance, a service station or carwash—and thus has substantial paved area not strictly for parking.

What evidence we have suggests these potential biases should not represent large threats. Our estimate that 70 percent of non-building area is parking is, again, probably conservative-many parcels have little landscaping - and if anything biases our parking counts downward. Figure 2 shows two aerial views of San Jose- one looking at an industrial area and one at a commercial/office area. Both suggest a dearth of landscaping. Building step-backs are more common on taller structures, but most buildings in Santa Clara County are not very tall. Eighteen percent of our parcels have no building at all, 50 percent are one-story, another 26 percent have two stories, 3.5 percent have three stories, and only 2.5 percent have four stories or more. Step-backs are thus unlikely.

\footnotetext{
5 We note that some of the landscaping and open space requirements are intended to offset the negative effects of paved areas devoted to parking.
} 

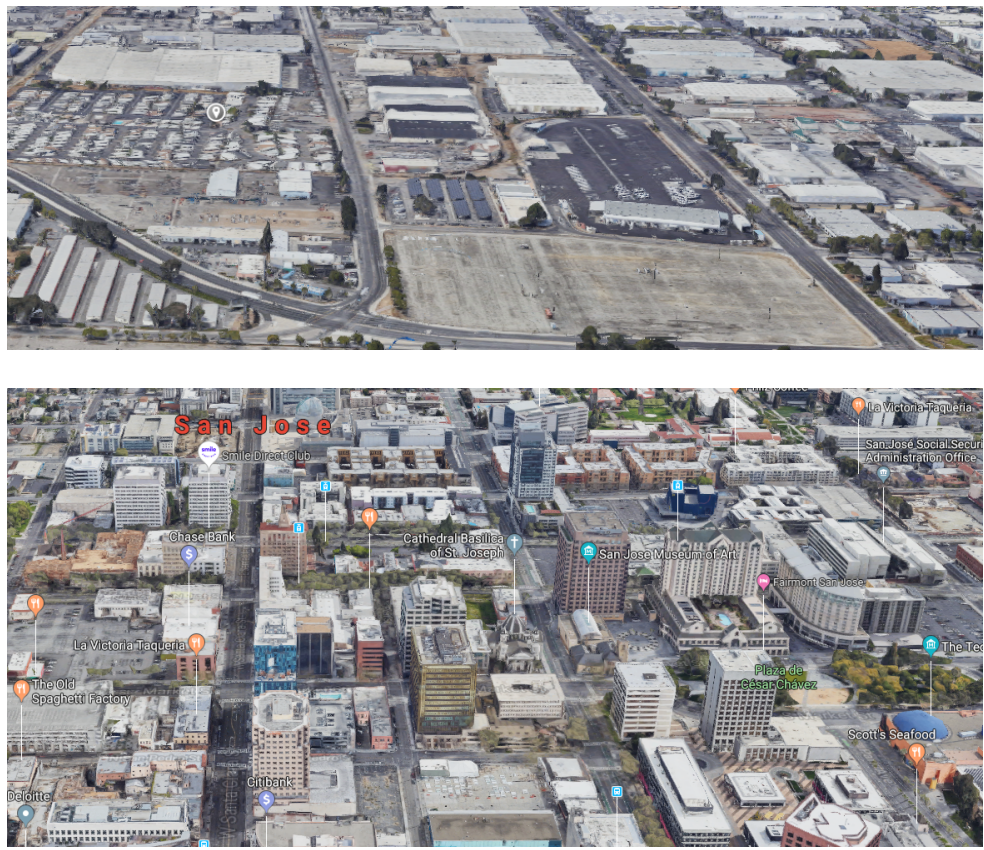

Figure 2. Industrial and commercial San Jose (Google Maps)

Structured parking presents a potentially larger confound. Fortunately (for us) much of Silicon Valley's parking appears to be surface. (In the conclusion, we return to the question of why this is so.) Structured parking is more common with multistory buildings, and (again) over 90 percent of our parcels have buildings that are two stories or less. Some newer buildings, particularly large office campuses and developments at universities like Stanford, do have structured parking, and we will likely undercount parking on these parcels. We may also undercount the parking associated with multifamily housing. Multifamily housing in California often has covered parking, under awnings or in rows of attached garages. We may erroneously count these spaces as part of the building area, biasing our parking estimates downward.

Most of our likely biases, in summary, will generate undercounts, and make our estimates conservative, especially for newer buildings. We still face the problem of missing and inconsistent data in some fields, but we address this problem by carrying out a second analysis that focuses primarily on office parcels, which have the least missing or inconsistent data. Of the 19,209 parcels we have, 3,648 are office parcels.

We validate our estimates by using Google Maps aerial imagery to visually inspect two subsets of our data: a random sample of 80 parcels, and a sample of outliers-the 113 parcels that by our method had over 2,000 parking spaces. Visually inspecting the randomly-selected 80 parcels generated estimates that were on average within 3 percent of ours. Examining the 113 outliers suggested that about half were erroneous: while some actually had large amounts of parking, others included little to none, for a variety of reasons. These reasons included parcels used for manufacturing that had substantial paved area but little parking (for instance, large areas for equipment storage); parts of university campuses with large open spaces; and parcels listed as "vacant urban," which often lacked buildings, and for which we knew nothing else about the actual use. Fortunately, only about 5 percent of these outlier parcels were office uses; most were industrial or vacant urban. We manually updated the parking estimates for these 113 parcels based on our visual inspection of aerial imagery. 


\subsection{Identify binding regulations}

Having estimated the parking inventory, we turn to the question of whether the zoning created the parking. As we discussed above, parking requirements may not bind. Firms and developers might build parking with little consideration of the zoning. Most evidence, however, suggests otherwise: developers, especially in urban environments, build to the standard or very close to it (Cutter \& Franco, 2012; Gabbe, 2018; Gabbe, Pierce, \& Clowers, 2020; Guo \& Ren, 2013; Li \& Guo, 2017; Manville, 2013; McDonnell, Madar, \& Been, 2011; Willson, 1995). ${ }^{6}$

We follow (roughly) the method laid out in McDonnell et al. (2011), assuming that parking counts of up to 120 percent of the requirement suggest a requirement that binds. ${ }^{7}$ The 120 percent upper bound, rather than 100 percent, lets us account for idiosyncrasies that can arise when developers actually provide parking on a site. Sometimes developers supply required parking and are left afterward with a piece of land (or building area) that cannot be used for anything except more parking. For example: suppose the developer of a 12-unit building needs 18 parking spaces to satisfy a 1.5 space per unit parking requirement. The developer puts the parking on the building's first floor, which actually has room for 20 spaces. Once the developer has given the first floor over to parking (a decision forced by the requirement) it makes little sense not to build the last two spaces, since it would be difficult to use the space in a parking garage for anything else. The developer thus exceeds the requirement, but does so because of the requirement.

We consider any parking below the requirement to be evidence that the requirement binds. This judgment might seem odd, but parking requirements are generally enforced, so parcels with less parking than the zoning would require are usually evidence that developers have exerted effort to avoid the zoning. These efforts might involve securing a variance or other permission, or-in the case of San Josebuilding a Planned Development (PD) to get lower parking requirements than under the baseline zoning. In these circumstances the developer deviates from the requirement, but the requirement still exerts influence, in that it is an anchor determining the developer's actions. Indeed, the presence of exemptions and other escape valves for developers suggests a tacit acknowledgment by planners that parking requirements often exceed market demand. So too do incentive programs that let developers build less parking if they supply affordable housing. Whatever the merits of these programs, they suggest that the parking requirement is not just burdensome but also not based on how much parking the building needs to be economically viable (Manville \& Osman, 2017).

To measure bindingness, we first inventory the parking requirements themselves. For each of the seven cities in our sample, we track the evolution of parking requirements, as best we can, for as many land uses as possible. Cities do not keep reliable records of their older requirements, unfortunately, so some data was missing for some cities for the decades before 1970. We found, however, that requirements have been generally consistent across both cities and time, as Figures 3 and 4 show. For example, in 2019 parking requirements for office uses ranged from 3.3 to 4.2 spaces per 92.9 square meters (1,000 square feet), with a median of 3.5 . The range in 1990, by comparison, was 3.3 to 5.0 spaces with a median of 4.0. For a 2-bedroom apartment during 1990-2019, the range narrowed slightly and the median requirement of 2.0 spaces per housing unit is unchanged. The general impression is one of rules that vary little by place, and that are revisited only rarely over time.

\footnotetext{
${ }^{6}$ As an anecdote, consider the Apple headquarters in Cupertino. The firm's campus has 11,000 parking spaces for 14,000 employees and devotes more space to parking than to offices (How not to create traffic jams, pollution and urban sprawl, 2017). These spaces were largely the product of zoning: Apple's original plan for the headquarters called for 1,200 parking spaces, but the city required far more (Chilton \& Bream, 2017).

7 Our approach is slightly more conservative than McDonnell et al. (2011), who assume $125 \%$ as the binding threshold.
} 


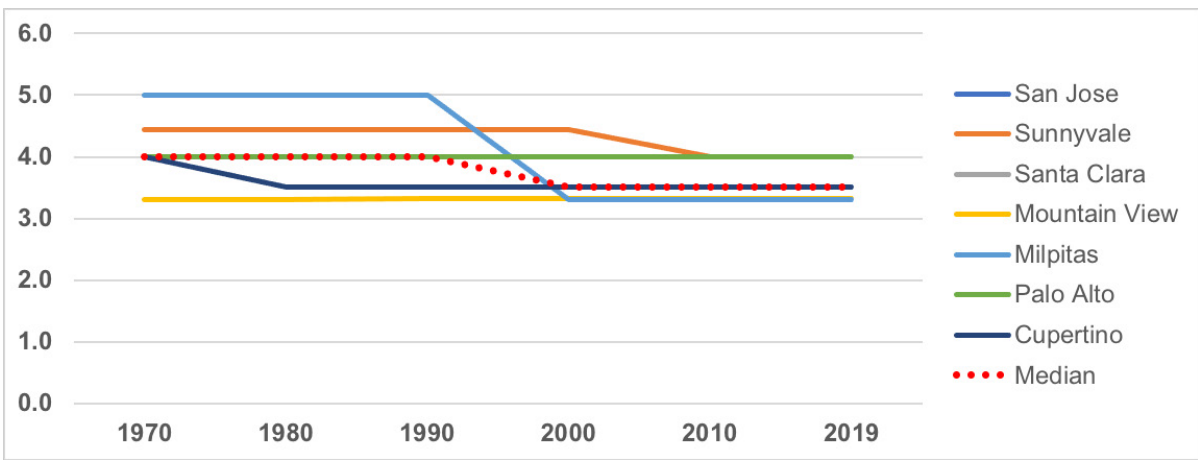

Figure 3. Required parking per 92.9 square meters (1000 square feet) of office space, by city (1970-2019)

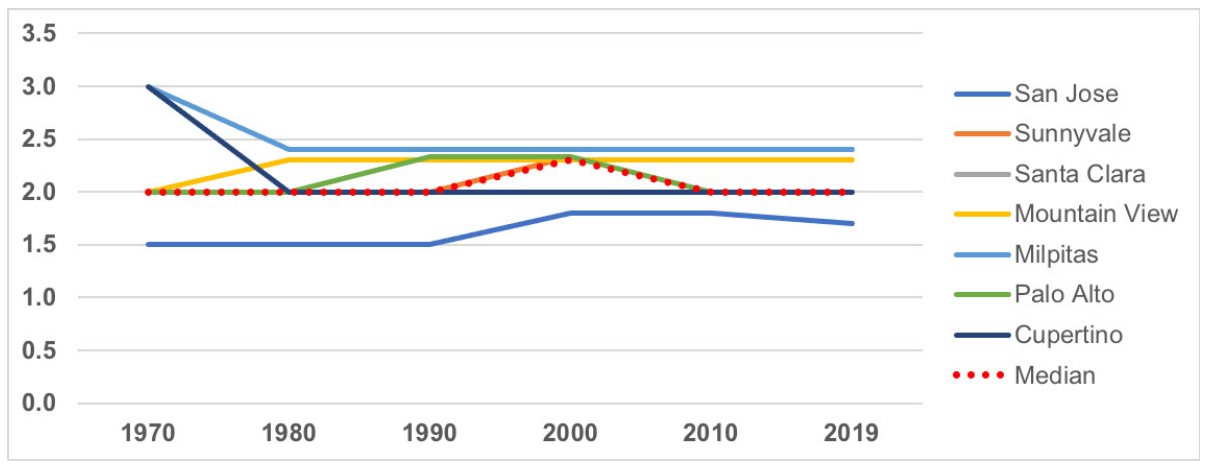

Figure 4. Required parking per unit for 2-bedroom multifamily, including guest parking, by city (1970-2019)

Having gathered the parking requirements, we next match the requirements to each developed parcel and generate an estimate of each parcel's required parking. For example, a 2,787 square meter (30,000 square foot) office building constructed in 2019 might require 105 parking spaces $(3.5$ multiplied by 30). We then compare our estimate of required parking on that parcel with our estimate of actual parking provision there, to determine if the requirement binds (e.g., we determine if actual parking provision is below 120 percent of the parking requirement).

A missing data problem arises here. The assessor data lack a year built for nearly $17 \%$ of the parcels in our sample. These parcels, moreover, account for about $24 \%$ of the cities' total parking. The assessor database also, unfortunately, provides little further detail about these parcels. Roughly a third are classified as "vacant urban," suggesting they have no building. Another 13 percent are churches, and thus not land uses we are concerned with. We drop both these from our analysis. Another 4 percent are classified under an industrial use code that can include parking lots. And 28 percent have land use codes for retail or office (which can include parking for those uses).

This latter group likely represents a larger problem. Some office and retail developments provide parking for their buildings on an adjacent parcel. They use one parcel almost entirely for a building, and an adjoining parcel as a surface parking lot. The parcel with the parking, moreover, gets assigned a use code that reflects the adjacent use (e.g., office or retail, not parking). This means that a strict parcel level analysis could show one office parcel with very little parking, and an adjacent office parcel with nothing but parking — suggesting that on that parcel the parking requirement does not bind (even if, as is likely the case, the developer acquired the second parcel primarily to meet the parking requirement). Conceivably we could account for this issue by explicitly linking the parking parcel to the building parcel, but the assessor data have no identifiers making it simple to do so. As a result, we will likely have some parcels where we inaccurately consider the parking requirement nonbinding, making our estimates (again) conservative. 


\subsection{Create a counterfactual}

With these data assembled, we create a counterfactual scenario that assumes that the seven cities reduced their parking requirements by 50 percent in 2000 . We choose a 50 percent reduction because this would have brought most Santa Clara County municipalities' parking requirements closer to those of many denser West Coast cities, including San Francisco, Seattle, and Portland. We choose the 2000-2017 period to demonstrate the effects of nearly two decades of parking reductions. This time period also roughly parallels the rise in awareness about the social costs of parking requirements and the reduction or elimination of such requirements in cities such as San Francisco.

The counterfactual proceeds as follows. We assume first that the parking requirements are reduced by 50 percent, and second that any development in our sample with a binding parking requirement (120 percent of the code or less) would build to the new, lower requirements instead. (In a sensitivity analysis discussed later, we alter these assumptions.) For developments where the requirement did not bind, we assume that lowering the requirement yields no change in parking provision. Based on these assumptions, we calculate a total number of parking spaces not built, then convert that, on a parcel basis, to space saved.

Supplying less parking would allow developers to produce more building area, but for a variety of reasons, ranging from the availability of capital to the idiosyncrasies of particular parcels and buildings, developers will not convert every foregone square meter of parking into a new square meter of built space. We therefore conservatively assume that half of the saved space in parking could become built area. We also assume, again conservatively, that densities would increase only on parcels developed between 2000 and 2017. We ignore the possibility, although it is plausible, that lower parking requirements might trigger new development on vacant parcels, or encourage redevelopment of some parcels that were built on earlier.

We next assume that more built area would let the parcel accommodate more jobs. To estimate how many, we combine our assessor data with data from the Bureau of Labor Statistics' Zip Code Business Patterns, and divide total built square feet by total employment. This calculation tells us that in our seven cities there is one office employee per 23.6 square meters (254 square feet) of office building space, and one employee per 64.1 square meters (690 square feet) of other nonresidential building space (across all built space, the average is one employee per 47.8 square meters or 515 square feet). These estimates are roughly in line with national estimates of commercial space. In 2018, for example, Cushman-Wakefield estimated that office density in most metropolitan areas was slightly below one worker per 27.9 square meters (300 square feet), but that in more expensive markets it was as low as 1 worker per 12.5 meters (135 square feet); Silicon Valley's ratio was one worker per 17.7 square meters (191 square feet) (Cushman \& Wakefield, 2018).

Using these ratios, we estimate the additional jobs that could be held in built space added as a result of foregone parking. We pay particular attention to increased office jobs both because office work is arguably the engine of Silicon Valley's agglomeration, and also because—as we have discussed—our office data appear to suffer least from missingness and other ambiguities.

To anticipate our results: the time period we are considering is both relatively short and characterized by relatively little actual development. The 50 percent parking requirement reduction, moreover, is substantial but not gigantic. As such, we expect less dramatic results than those of Hsieh and Moretti (2019), who simulated a large 50-year reduction in the overall zoning stringency of the New York, San Francisco and San Jose metropolitan areas. Hsieh and Moretti assumed that from 1960 forward these regions would have regulatory regimes no stricter than the average US metropolitan statistical area (MSA). This is a sizeable change: San Francisco's zoning in 2006, according to the Wharton Land Use Regulatory Index, is 15 times as strict as Chicago's, which is close to the national average (Gyourko, Saiz, 
\& Summers, 2008). Our simulation involves smaller changes over shorter time, and our results should be less momentous as well.

\subsection{Estimating the relationship between reform, density and wages}

The steps to this point let us estimate the number of jobs that could be associated with parking reform. Our next question is where within the region those jobs would be-how they would fit into Silicon Valley's existing agglomeration. Agglomeration's logic suggests that some parts of Silicon Valley are more productive than others, and that adding jobs in these more productive areas should yield higher returns (in wages and output) than spreading new jobs evenly across the region.

To estimate these returns, and make this comparison, we use zip codes as subregions, because zip codes are smallest level of geography that have wage, firm, and employment data. Our first step is to estimate a zip code level relationship between job density and wages in Silicon Valley. We make this estimate through a simple model of the wage elasticity of density, similar to those employed by Glaeser and Kahn (2004) and Anderson, Klaesson, and Larsson (2016). Our sample is every zip code in the San Francisco Bay Area, which is the Consolidated Statistical Area (CSA) that contains both the San Francisco and Santa Jose MSAs. We use the CSA rather than the MSA both to increase our sample size and because the MSAs within it do share an underlying industrial base. The model is:

$\ln \left(w_{j}\right)=\beta_{0}+\beta_{1} \ln \left(e_{\mathrm{j}}\right)+\beta_{1} \ln +\eta+\mu$

where $\ln \left(w_{j}\right)$ is the log of wages in zip code $j, \ln \left(e_{j}\right)$ and $\ln \left(p_{j}\right)$ are the $\log$ of employment and population density in zip code $\mathrm{j}$, respectively, $\eta$ is a zip-code-specific fixed effect, and $\mu$ is the error term. The wage and employment count data for this regression come from the Bureau of Labor Statistics Zip Code Business Patterns, while the population counts come from the American Community Survey.

The model gives us an elasticity of wages with respect to employment density. From there our method is straightforward: we aggregate our parcel-level job estimates to the zip code level, and calculate, for each zip code, the increase in employment and increase in employment density. We then apply our wage elasticity to this employment density to calculate an increase in each zip code's average wage, and multiply that wage across all jobs (existing jobs and new jobs) to generate each zip code's new total payroll. Lastly, we sum this new zip code payroll to generate a regionwide counterfactual payroll, which we compare with a) the current payroll and b) a second counterfactual estimate where we assume that Silicon Valley creates the same number of new jobs, but that these jobs are spread evenly across the region, rather than primarily in places where parking reform has the largest consequences.

One note related to this analysis: we estimate an elasticity using the density of all employment, but our counterfactual wage estimates are based only on the growth in office jobs. Again, we focus on this office job growth because the office parcels are least prone to missing data problems, and thus easiest to assign to zip codes. We expect that office jobs will account for most of the added employment, so restricting our analysis in this way will not change our results much but will make them slightly conservative.

\section{$5 \quad$ Results}

Across our sample, large shares of land, across almost all land use types, are devoted to parking. Table 2 breaks these proportions down by land use. Nearly 40 percent of the average non-manufacturing 
industrial parcel, and about 44 percent the average retail parcel is devoted to parking. The parking share of multifamily parcels is similar-at about 41 percent—but recall that we anticipated undercounts here, because a lot of multifamily residential parking is covered, and thus eludes both the building-footprint approach and visual inspection from the air. For offices, the land use category with probably the most reliable data, 42 percent of the average parcel is parking space.

Table 2. Parcels and parking land area by land use category

\begin{tabular}{lrrrrr}
\hline Use Category & Parcels & \% of parcels & $\begin{array}{r}\text { Total parcel land } \\
\text { area (acres) }\end{array}$ & $\begin{array}{r}\text { Median parcel } \\
\text { land area (acres) }\end{array}$ & $\begin{array}{r}\text { Median \% land } \\
\text { area as parking }\end{array}$ \\
\hline Industrial non-manufacturing & 3,687 & $19 \%$ & 9,623 & 1.3 & $39 \%$ \\
Manufacturing & 449 & $2 \%$ & 1,926 & 1.1 & $39 \%$ \\
Multifamily & 4,819 & $25 \%$ & 6,844 & 0.3 & $41 \%$ \\
Office & 4,140 & $22 \%$ & 4,373 & 0.2 & $42 \%$ \\
Other urban & 563 & $3 \%$ & 416 & 0.5 & $54 \%$ \\
Public/quasi-public & 313 & $2 \%$ & 3,679 & 1.7 & $60 \%$ \\
Retail & 5,238 & $27 \%$ & 5,282 & 0.4 & $44 \%$ \\
\hline All use categories above & $\mathbf{1 9 , 2 0 9}$ & $\mathbf{1 0 0} \%$ & $\mathbf{3 2 , 1 4 4}$ & $\mathbf{0 . 5}$ & $\mathbf{4 1 \%}$
\end{tabular}

\subsection{Parking land area and spaces}

If we convert the share of land in parking into an estimated number of spaces, the result suggests that these seven cities have 311,308 multifamily parking spaces attached to housing of five or more units, and just over 1.45 million non-residential off-street spaces. While we did not calculate a parking inventory for residential parcels of four units or less, we can use Census data to estimate this inventory. About 90 percent of these units are in detached and attached single-family homes (specifically, about 73 percent are detached single-family homes, and another 16 percent attached single-family). Because it is not unusual for a single-family home in Santa Clara County to have a two-car garage and a driveway, we can assume, almost certainly conservatively, that each of these homes has off-street parking for three vehicles. This gives three spaces per 368,345 structures with five units or less, or another 1.1 million spaces. ${ }^{8}$ Altogether, this exercise suggests that these seven cities have, again conservatively, 2.87 million parking off-street parking spaces. This works out to about 2.8 spaces per residential vehicle, and 2 spaces per person. It also suggests that these seven cities have about 80.3 square kilometers (31 square miles) of off-street parking on 644.9 square kilometers ( 249 square miles) of land, meaning that nearly 13 percent of their land area is off-street parking. By way of comparison, Chester et al. (2015) estimate that L.A. County is 14 percent parking. Their estimate, however, includes all land uses, and also includes on-street parking, which they suggest is 15-20 percent of the county total. Our calculations then, strongly suggest that compared to LA, a larger proportion of Silicon Valley is off-street parking.

Our estimates also suggest that parking in Silicon Valley is supplied most heavily on parcels developed in the postwar 20th century (although we note again that even after dropping some land use categories, our sample lacks year of development data for 10 percent of parcels, which hold 13.6 percent of the parking). We summarize this finding in Table 3. Parcels developed before 1940 account for over 7 percent of the parcels in our sample, but less than 2 percent of the parking spaces. For offices in particular, the relevant proportions are 8.5 percent and 1.7 percent. In the years since 1940, the share of land

${ }^{8}$ This estimate is also conservative because 10 percent of these structures hold more than one unit and may thus also more parking spaces. 
area in parking on both parcels overall and on office parcels in particular has generally risen, although it has risen less for offices. Most of the region's parking (68 percent) was supplied between 1950 and 2000, largely because most of its buildings ( 69 percent) were also supplied during this period. Only 15 percent of the seven cities' parking has been built since 2000-this parking is the focus of our counterfactual scenario.

Table 3. Summary of parcels and parking land area by decade of construction

\begin{tabular}{|c|c|c|c|c|c|c|c|c|c|c|}
\hline \multirow[t]{2}{*}{ Decade } & \multicolumn{2}{|c|}{ Parcel count } & \multicolumn{2}{|c|}{$\%$ of parcels } & \multicolumn{2}{|c|}{ Parking spaces } & \multicolumn{2}{|c|}{$\%$ of parking spaces } & \multicolumn{2}{|c|}{$\begin{array}{c}\% \text { land area as } \\
\text { parking }\end{array}$} \\
\hline & All & Office & All & Office & All & Office & All & Office & All & Office \\
\hline None & 1,913 & 321 & $10.00 \%$ & $8.80 \%$ & 239,386 & 29,036 & $13.60 \%$ & $10.70 \%$ & $32 \%$ & $44 \%$ \\
\hline Pre-1940 & 1,406 & 311 & $7.30 \%$ & $8.50 \%$ & 34,079 & 4,664 & $1.90 \%$ & $1.70 \%$ & $20 \%$ & $39 \%$ \\
\hline 1940 & 650 & 133 & $3.40 \%$ & $3.60 \%$ & 16,286 & 1,785 & $0.90 \%$ & $0.70 \%$ & $38 \%$ & $40 \%$ \\
\hline 1950 & 2,470 & 300 & $12.90 \%$ & $8.20 \%$ & 89,278 & 6,617 & $5.10 \%$ & $2.40 \%$ & $41 \%$ & $42 \%$ \\
\hline 1960 & 3,794 & 435 & $19.80 \%$ & $11.90 \%$ & 200,976 & 18,735 & $11.40 \%$ & $6.90 \%$ & $36 \%$ & $43 \%$ \\
\hline 1970 & 2,889 & 502 & $15.00 \%$ & $13.80 \%$ & 347,817 & 43,950 & $19.70 \%$ & $16.20 \%$ & $37 \%$ & $42 \%$ \\
\hline 1980 & 2,953 & 777 & $15.40 \%$ & $21.30 \%$ & 339,654 & 65,265 & $19.30 \%$ & $24.10 \%$ & $39 \%$ & $47 \%$ \\
\hline 1990 & 1,124 & 231 & $5.90 \%$ & $6.30 \%$ & 225,284 & 35,267 & $12.80 \%$ & $13.00 \%$ & $44 \%$ & $48 \%$ \\
\hline 2000 & 1,368 & 492 & $7.10 \%$ & $13.50 \%$ & 162,390 & 33,331 & $9.20 \%$ & $12.30 \%$ & $44 \%$ & $44 \%$ \\
\hline 2010 & 642 & 146 & $3.30 \%$ & $4.00 \%$ & 106,688 & 32,439 & $6.10 \%$ & $12.00 \%$ & $43 \%$ & $44 \%$ \\
\hline Total & 19,209 & 3,648 & $100.00 \%$ & $100.00 \%$ & $1,761,838$ & 271,089 & $100.00 \%$ & $100.00 \%$ & $38 \%$ & $44 \%$ \\
\hline
\end{tabular}

Lastly, across all parcels, roughly 62 percent of residential developments and 46 percent of nonresidential developments (but 61 percent of office developments) fall into our definition of binding, in that they provide less than 120 percent of the requirement. We consider these figures conservative, for reasons we have laid out above.

\subsection{Counterfactual scenario}

We use these data to build our counterfactual scenario, which we show Table 4. Reducing the parking requirements by 50 percent in these seven cities in the year 2000 would result in 36,726 fewer parking spaces, totaling some 1.02 million square meters (11 million square feet). 9 The average parcel built under lower requirements would devote only 38 percent of its land area to parking, as opposed to the current mean of 44 percent. By our estimate this new space could be repurposed into over 6,700 additional multifamily housing units, and into nonresidential space that could hold 12,886 additional jobs. Of these jobs, almost 10,400 would be office jobs, since office jobs have higher densities than other categories.

To put these estimates in perspective, in reality these seven cities added 34,636 jobs between 2000 and 2017. Our projected increase thus amounts to a 37 percent increase in job growth, with office jobs accounting for 92 percent of the net jobs created.

\footnotetext{
${ }^{9}$ By comparison, Guo and Ren (2013) found that developers built 40\% less residential parking than would have been previously required after London (UK) converted parking minimums to parking maximums, and Gabbe et al., (2020) found that Seattle developers built $40 \%$ less residential parking than would have been previously required in areas where off-street parking requirements were reduced or eliminated. One possible reason for these larger estimates is that the typical residential building in London has fewer spaces than the typical office parcel in Silicon Valley, so equal-sized reductions in the number of spaces yield very different proportional reductions.
} 
Table 4. Comparison between actual and counterfactual

\begin{tabular}{lrrrrrr}
\hline Use category & $\begin{array}{r}\text { Parking } \\
\text { spaces-Actual }\end{array}$ & $\begin{array}{r}\text { Parking } \\
\text { spaces- } \\
\text { Counterfactual }\end{array}$ & $\begin{array}{r}\text { Parking } \\
\text { change in } \\
\text { counterfactual } \\
\text { (spaces) }\end{array}$ & $\begin{array}{r}\text { Parking } \\
\text { change in } \\
\text { counterfactual } \\
\text { (sq. m) }\end{array}$ & $\begin{array}{r}\text { Additional } \\
\text { housing } \\
\text { units* }\end{array}$ & $\begin{array}{r}\text { Additional } \\
\text { employment** }\end{array}$ \\
\hline $\begin{array}{l}\text { Industrial and } \\
\text { manufacturing }\end{array}$ & 672,137 & 671,382 & -755 & $-21,047$ & $\mathrm{n} / \mathrm{a}$ & 164 \\
Multifamily & 308,372 & 299,396 & $-8,976$ & $-250,158$ & 6,732 & $\mathrm{n} / \mathrm{a}$ \\
Office & 283,640 & 266,050 & $-17,590$ & $-490,242$ & $\mathrm{n} / \mathrm{a}$ & 10,388 \\
Other urban & 28,089 & 27,576 & -513 & $-14,289$ & $\mathrm{n} / \mathrm{a}$ & 111 \\
$\begin{array}{l}\text { Public/quasi- } \\
\text { public }\end{array}$ & 120,949 & 120,949 & - & & $\mathrm{n} / \mathrm{a}$ & - \\
Retail & 344,556 & 335,664 & $-8,892$ & $-247,841$ & $\mathrm{n} / \mathrm{a}$ & 2,223 \\
\hline Total & $\mathbf{1 , 7 5 7 , 7 4 3}$ & $\mathbf{1 , 7 2 1 , 0 1 7}$ & $-\mathbf{3 6 , 7 2 6}$ & $\mathbf{- 1 , 0 2 3 , 5 7 7}$ & $\mathbf{6 , 7 3 2}$ & $\mathbf{1 2 , 8 8 6}$
\end{tabular}

* Assumes each reduced parking space would lead to 0.75 new residential units.

** Assumes each reduced parking space would lead to 13.9 non-residential sq. m (150 sq. ft.); employment is calculated assuming 1 employee per 23.4 building sq. $\mathrm{m}$ ( 254 sq. ft.) for office and 1 employee per 64.1 sq. m (690 sq. ft.) for other employment uses.

\subsection{Sensitivity analysis}

Two large assumptions that feed our empirics are the size of the change in parking requirements, and the threshold at which we consider a parking requirement binding. Because both of these measures are arguably arbitrary, we test the robustness of our analysis by running the simulation in three further ways. First, we keep the parking requirement reduction at 50 percent, but lower the threshold for bindingness to 100 percent of the original requirement. Second, we reduce the amount of parking required by only 25 percent but return the bindingness level to 120 percent. And third, we run the simulation with a 25 percent reduction in parking requirements and a 100 percent bindingness threshold. These alterations all obviously change the results and reduce the predicted increase in jobs. Across all these scenarios, the new job estimates range between 3,250 and 12,886, with the office job increase ranging between 2,570 to 10,388 . These are admittedly large changes in the result. But the robustness checks themselves introduce large changes: we cut the zoning change in half and drop the bindingness threshold by 20 percent. Even with these large changes, however, the low estimate still suggests a job increase substantially larger than what actually occurred. And remember that all these estimates_-including the baseline-are built on assumptions that are consistently conservative.

\subsection{Zip code analysis of wage and payroll}

We now turn to the location of these new jobs, and their potential impact on wages. As discussed in the methods section, our first step is a simple regression of wages on employment density. Table 5 shows the output, which suggests that across the Bay Area, a 10 percent increase in zip code employment density is associated with a 1.3 percent increases in wages paid by employers. The relationship is statistically significant, and robust to dropping all zip codes in the City of San Francisco, which is the densest part of the region. 
Table 5. Wage elasticity of density

\begin{tabular}{ll}
\hline Log of job density & $0.133^{* * *}$ \\
Log of population & $-0.102^{* * *}$ \\
Constant & 11.284 \\
\hline R-squared & 0.751 \\
Number of observations & 305 \\
Note: $^{*} \mathrm{p}<0.1,{ }^{* *} \mathrm{p}<0.05,{ }^{* * *} \mathrm{p}<0.01$. Output of city fixed effects are suppressed.
\end{tabular}

We can now combine this elasticity with our counterfactual estimates, to estimate a wage impact associated with parking reform. Our seven cities have 49 zip codes that include office parcels, and our counterfactual suggests that reform would accommodate about 10,400 additional office jobs, which would raise employment density by about 1.1 percent.

Summing our parcel level estimates of additional jobs to the zip code level shows that reduced parking requirements would increase the number of office jobs in the median zip code by about 16 . The distribution of these gains, however, is highly uneven, consistent with the idea that firms and employment cluster within regions (see figure 5). In 15 zip codes that have little employment and largely non-binding parking requirements, office employment would not change. Another 12 zip codes, in contrast, would add between 126 and 1,746 additional jobs. About 67 percent of the overall job growth (almost 7,000 jobs) is in five zip codes, and 88 percent ( 9,173 jobs) is in ten zip codes. The same pattern holds for increases in employment density: in many zip codes it would not rise at all, but in some of the highest-wage zip codes it would rise between 4 and 8 percent.

These zip codes with the largest job gains are in the most productive areas of Silicon Valley, straddling the 101 corridor and include offices for global companies including Google, LinkedIn, Cisco, and Intel. (Go, 2019). New office employment by zip code in our counterfactual is strongly correlated with the zip code average wage $(\mathrm{r}=0.6)$, and with venture capital investment $(0.6) .{ }^{10} \mathrm{Visual}$ assessment of these zip codes shows many conventional office parks with sizable parking lots.

\footnotetext{
${ }^{10} \mathrm{Zip}$ code data on venture capital investment come from Pitchfork.
} 


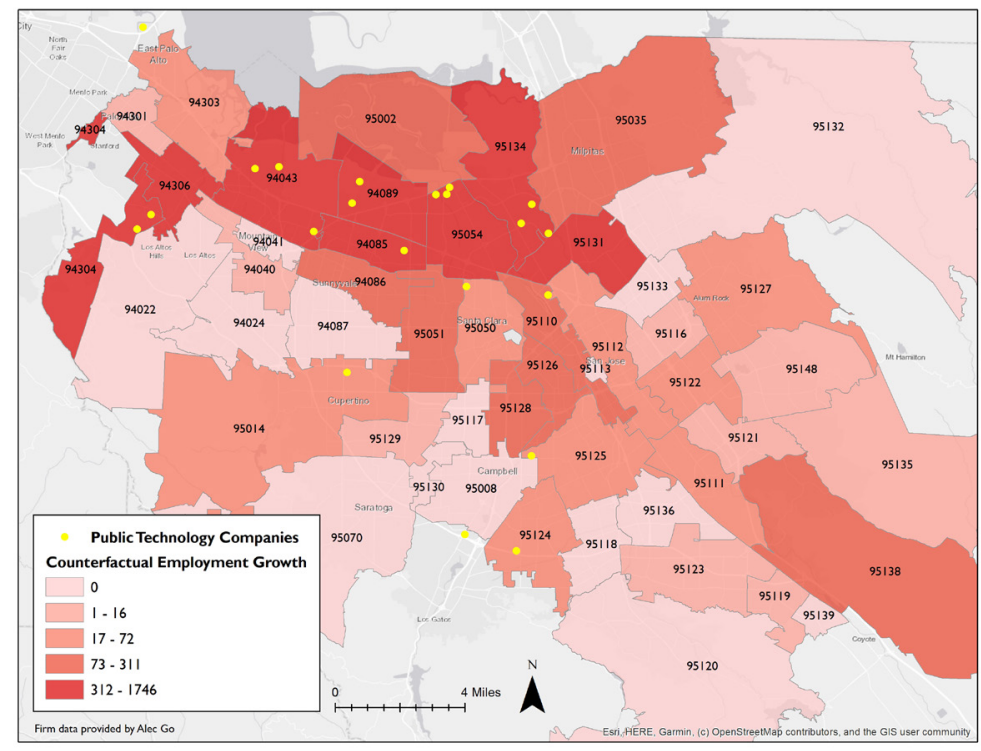

Figure 5. Office employment change in counterfactual by zip code and Silicon Valley public technology companies

If we apply our computed elasticity to each zip code's new employment density, we see a similar pattern. Across all zip codes, the median wage gain is only $\$ 14$. But in the zip codes where employment density increases by 3 percent or more, wage gains range from over $\$ 600$ to over $\$ 1,400$ annually. Because these places also have more jobs, our counterfactual generates a regionwide increase in payroll of $\$ 1.7$ billion annually (from about $\$ 109.2$ billion to $\$ 110.9$ billion). Of this $\$ 1.7$ billion payroll increase, $\$ 1.5$ billion (88\%) is associated with 10,400 new jobs, while $12 \%$ is attributable to zip code-level wage increases from density.

Finally, if we redo the calculations above but assume the new jobs are spread evenly across the 49 zip codes, the median zip code would see larger wage gains ( $\$ 135$ annually), but the regionwide increase in total payroll would be nearly $\$ 700$ million smaller, because many of the new jobs would be shifted to lower-wage zip codes. Thus parking reform would deliver returns not just by allowing more jobs, but by allowing jobs in those places where the returns to new employment are highest.

\section{Discussion and conclusion}

Our analysis suggests that a substantial share of multifamily and non-residential land in the most economically productive parts of Silicon Valley is consumed by parking spaces, and that much of that parking is in surface spaces. A majority of those spaces, furthermore, appear to exist only because of parking requirements, suggesting that at least some of them are economically superfluous. This fact in turn suggests a large opportunity cost: government parking mandates are reserving some of the most valuable land on earth for vehicle storage, rather than employment- or income-generating uses.

Our estimates suggest that had the seven most economically productive cities in Silicon Valley reduced their parking requirements by 50 percent in the year 2000, the region would have added almost 13,000 additional jobs. These jobs would have been located overwhelmingly in the highest productivity zip codes of Silicon Valley and added over \$1 billion to the region's payroll.

To the extent our analysis is reasonable, it reinforces existing evidence about the wastefulness of requiring parking. An additional point is that parking requirements likely make Silicon Valley not just less 
productive than it might otherwise be, but also more environmentally resource-intensive. A landscape of surface parking is a landscape of driving, so parking depresses Silicon Valley's net social benefits by reducing its agglomerative benefits and increasing its environmental costs, including through suppressing transit ${ }^{11}$ ridership and increasing traffic congestion.

Our analysis also illustrates how high parking requirements lock in auto-oriented land use patterns for decades, if not generations. ${ }^{12}$ Even assuming nearly 20 years of development under much lower parking standards, our counterfactual shows that Silicon Valley would still be considerably less dense than the other highly-productive cities and regions mentioned earlier. Silicon Valley cities should be aware that there will be a lag between parking reducing requirements and seeing major changes to urban form.

Counterfactual exercises of the sort we present are of course always speculative, and sensitive to the assumptions underlying them. Our findings are more illustrative than definitive. Nevertheless, at each step of our analysis we have been conservative. We are conservative in our parking counts, in how we treat missing data or ambiguous parcels, in how we estimate binding requirements, in how we convert foregone parking spaces into new built space, and in estimating zip-code increases in employment. There is good reason to think our conclusions err low.

One anomaly of Silicon Valley that we do not explore, but that warrants further scrutiny, is why so much parking in the region is in surface lots. Why haven't more landowners unlocked the value of their parcels by converting their surface parking to structured, and freeing up much of the land for other uses? Shoup (2011) estimates that when surface parking costs $\$ 10,000$ per space to supply, converting an acre of surface parking to structured parking becomes rational when land is between $\$ 323$ and $\$ 388$ per square meter ( $\$ 30$ to $\$ 36$ per square foot). Structured parking in Silicon Valley may well cost more than $\$ 10,000$ per space. Nevertheless, the estimated value of single-family residential land in Silicon Valley is $\$ 1,518$ per square meter (\$141 per square foot) (Larson, Shui, Davis, \& Oliner, 2020). Assuming commercial land is even somewhat comparably valued, many parcels could profitably convert their surface parking to structures. The fact that they have not suggests an inertia in land and property markets that warrants further scrutiny.

\section{Acknowledgements}

We thank two anonymous peer reviewers for their thoughtful comments. We appreciate the excellent research assistance of Cassie Halls. We are grateful for feedback from Donald Shoup on an earlier version of this manuscript. The Santa Clara County Assessor provided important parcel-level data for our project. Lastly, this research was made possible by grants from the UCLA Institute of Transportation Studies and the California Department of Transportation.

\footnotetext{
${ }^{11}$ If a large parking lot surrounds a building and a light rail line stops nearby, the implied subsidy to driving is likely larger than the subsidy to transit, and driving will remain more convenient. Most people with a car will still have a strong incentive to drive. It is less the case, in short, that more transit makes parking less necessary. It is more the case that removing parking helps transit.

${ }^{12}$ While this paper was written prior to the COVID-19 pandemic, its findings remain relevant, and perhaps even more so. Uncertainty about future demand for office space—at least in the short term—-means that reducing or eliminating minimum parking requirements can allow firms to more nimbly adapt to changing times. Additionally, the extensive provision of surface parking in Silicon Valley remains an inefficient and environmentally harmful use of land.
} 


\section{References}

Ahlfeldt, G. M., \& Pietrostefani, E. (2019). The economic effects of density: A synthesis. Journal of Urban Economics. https://doi.org/10.1016/j.jue.2019.04.006

Akbari, H., Shea Rose, L., \& Taha, H. (2003). Analyzing the land cover of an urban environment using high-resolution orthophotos. Landscape and Urban Planning, 63(1), 1-14. https://doi.org/10.1016/ S0169-2046(02)00165-2

Andersson, M., Klaesson, J., \& Larsson, J. P. (2016). How local are spatial density externalities? Neighborhood effects in agglomeration economies. Regional Studies, 50(6), 1082-1095. https://doi.org/1 $0.1080 / 00343404.2014 .968119$

Arzaghi, M., \& Henderson, J. V. (2008). Networking off Madison Avenue. The Review of Economic Studies, 75(4), 1011-1038. https://doi.org/10.1111/j.1467-937X.2008.00499.x

Carlino, G. A., Chatterjee, S., \& Hunt, R. M. (2007). Urban density and the rate of invention. Journal of Urban Economics, 61(3), 389-419. https://doi.org/10.1016/j.jue.2006.08.003

Chester, M., Fraser, A., Matute, J., Flower, C., \& Pendyala, R. (2015). Parking infrastructure: A constraint on or opportunity for urban redevelopment? A study of Los Angeles County parking supply and growth. Journal of the American Planning Association, 81(4), 268-286. https://doi.org/10.1080 /01944363.2015.1092879

Chilton, W., \& Bream, B. (2017, July 19). The high cost of free parking. Vox. Retrieved from https:// www.vox.com/videos/2017/7/19/15993936/high-cost-of-free-parking

City of Oakland/MTC. (2016). Downtown Oakland parking study technical memorandum \#2: Existing conditions. Retrieved from https://wbcapp.oaklandnet.com/cs/groups/public/documents/report/ b2fr/mdu3/-edisp/oak057179.pdf

City of San Jose. (2013). City of San Jose specific height limitation areas. Retrieved from https://www. sanjoseca.gov/home/showdocument?id=24013

Combes, P.-P., Duranton, G., \& Gobillon, L. (2008). Spatial wage disparities: Sorting matters! Journal of Urban Economics, 63(2), 723-742. https://doi.org/10.1016/j.jue.2007.04.004

Combes, P.-P., Duranton, G., \& Gobillon, L. (2012). The costs of agglomeration: Land prices in French cities. SSRN. Retrieved from https://papers.ssrn.com/sol3/papers.cfm?abstract_id=2210209

Cushman \& Wakefield. (2018). Space matters. Key office trends and metrics for occupiers. Chicago: Cushman \& Wakefield. Retrieved from http://creknowledgecenter.com/wp-content/uploads/2018/06/ Space-Matters-Spring-2018.pdf

Cutter, W. B., \& Franco, S. F. (2012). Do parking requirements significantly increase the area dedicated to parking? A test of the effect of parking requirements values in Los Angeles County. Transportation Research Part A: Policy and Practice, 46(6), 901-925. https://doi.org/10.1016/j.tra.2012.02.012

Duranton, G., \& Puga, D. (2004). Micro-foundations of urban agglomeration economies. In J. V. Henderson \& J.-F. Thisse (Eds.), Handbook of regional and urban economics (Vol. 4, pp. 2063-2117). Amsterdam: Elsevier. Retrieved from https://doi.org/10.1016/S1574-0080(04)80005-1

Duranton, G., \& Puga, D. (2015). Urban land use. In G. Duranton, J. V. Henderson, \& W. C. Strange (Eds.), Handbook of regional and urban economics (Vol. 5, pp. 467-560). Amsterdam: Elsevier. Retrieved from https://doi.org/10.1016/B978-0-444-59517-1.00008-8

Fort Hill Infrastructure Services. (2017). City of Portland parking study for Downtown, the Old Port, and the Eastern Waterfront. Boston: Fort Hill Infrastructure Services. Retrieved from http://www.portlandmaine.gov/DocumentCenter/View/18261/Portland-Parking-Study-Final-Report?bidId=

Gabbe, C. J. (2018). How do developers respond to land use regulations? An analysis of new housing in Los Angeles. Housing Policy Debate, 28(3), 411-427. https://doi.org/10.1080/10511482.2017. 1368031 
Gabbe, C. J., Pierce, G., \& Clowers, G. (2020). Parking policy: The effects of residential minimum parking requirements in Seattle. Land Use Policy, 91. https://doi.org/10.1016/j.landusepol.2019.104053

Ganong, P., \& Shoag, D. (2017). Why has regional income convergence in the U.S. declined? Journal of Urban Economics, 102, 76-90. https://doi.org/10.1016/j.jue.2017.07.002

Glaeser, E. L. (1998). Are cities dying? The Journal of Economic Perspectives, 12(2), 139-160. https://doi. org/10.2307/2646967

Glaeser, E. L., \& Gyourko, J. (2003). The impact of building restrictions on housing affordability. Federal Reserve Bank of New York Economic Policy Review, 9(2), 21-39.

Glaeser, E. L., \& Kahn, M. E. (2001). Decentralized employment and the transformation of the American city (Working paper No. 8117; Working Paper Series). Cambridge, MA: National Bureau of Economic Research. https://doi.org/10.3386/w8117

Glaeser, E. L., \& Kahn, M. E. (2004). Sprawl and urban growth. In Handbook of regional and urban economics (Vol. 4, pp. 2481-2527). Amsterdam: Elsevier.

Go, A. (2019). Silicon Valley map. Retrieved from https:/www.siliconvalleymap.org/

Graham, D. J. (2007). Agglomeration, productivity and transport investment. Journal of Transport Economics and Policy, 41(3), 317-343.

Graham, D. J., Melo, P. S., Jiwattanakulpaisarn, P., \& Noland, R. B. (2010). Testing for causality between productivity and agglomeration economies. Journal of Regional Science, 50(5), 935-951. https://doi.org/10.1111/j.1467-9787.2010.00676.x

Guo, Z., \& Ren, S. (2013). From minimum to maximum: Impact of the London parking reform on residential parking supply from 2004 to 2010? Urban Studies, 50(6), 1183-1200. https://doi. org/10.1177/0042098012460735

Gyourko, J., Saiz, A., \& Summers, A. (2008). A new measure of the local regulatory environment for housing markets: The Wharton residential land use regulatory index. Urban Studies, 45(3), 693729. https://doi.org/10.1177/0042098007087341

Harris, T. F., \& Ioannides, Y. M. (2000). Productivity and metropolitan density. In Discussion papers series (No. 0016). Medford, MA: Department of Economics, Tufts University. Retrieved from https:// ideas.repec.org/p/tuf/tuftec/0016.html

Hoehne, C. G., Chester, M. V., Fraser, A. M., \& King, D. A. (2019). Valley of the sun-drenched parking space: The growth, extent, and implications of parking infrastructure in Phoenix. Cities, 89, 186-198. https://doi.org/10.1016/j.cities.2019.02.007

How not to create traffic jams, pollution and urban sprawl. (2017, April 8). The Economist. Retrieved from https:/www.economist.com/briefing/2017/04/08/how-not-to-create-traffic-jams-pollutionand-urban-sprawl

Hsieh, C.-T., \& Moretti, E. (2019). Housing constraints and spatial misallocation. American Economic Journal: Macroeconomics, 11(2), 1-39. https://doi.org/10.1257/mac.20170388

Larson, W., Shui, J., Davis, M., \& Oliner, S. (2020). The price of residential land for counties, zip codes, and census tracts in the United States (Working paper 19-01). Washington, DC: Federal Housing Finance Agency. Retrieved from https:/www.fhfa.gov/PolicyProgramsResearch/Research/Pages/ wp1901.aspx

Leamer, E. E., \& Storper, M. (2001). The economic geography of the Internet age. Journal of International Business Studies, 32(4), 641-665.

Li, F., \& Guo, Z. (2017). Do parking maximums deter housing development? Journal of Planning Education and Research, 38(2), 183-197. https://doi.org/10.1177/0739456X16688768

Li, R. (2010, February 1). New York's aging buildings. Observer. Retrieved from https://observer. com/2010/02/new-yorks-aging-buildings/ 
Lucas, R. E., \& Rossi-Hansberg, E. (2002). On the internal structure of cities. Econometrica, 70(4), 1445-1476. https://doi.org/10.1111/1468-0262.00338

Manville, M. (2013). Parking requirements and housing development. Journal of the American Planning Association, 79(1), 49-66. https://doi.org/10.1080/01944363.2013.785346

Manville, M. (2017). Bundled parking and vehicle ownership: Evidence from the American Housing Survey. Journal of Transport and Land Use, 10(1), 27-55. https://doi.org/10.5198/jtlu.2016.730

Manville, M., Beata, A., \& Shoup, D. (2013). Turning housing into driving: Parking requirements and density in Los Angeles and New York. Housing Policy Debate, 23(2), 350-375. https://doi.org/10.1 080/10511482.2013.767851

Manville, M., \& Osman, T. (2017). Motivations for growth revolts: Discretion and pretext as sources of development conflict. City \& Community, 16(1), 66-85. https://doi.org/10.1111/cico.12223

Manville, M., \& Pinski, M. (2020). Parking behavior: Bundled parking and travel behavior in American cities. Land Use Policy, 91,103853. https://doi.org/10.1016/j.landusepol.2019.02.012

Manville, M., \& Shoup, D. (2005). Parking, people, and cities. Journal of Urban Planning and Development, 131(4), 233-245. https://doi.org/10.1061/(ASCE)0733-9488(2005)131:4(233)

Marshall, A. (1890). Principles of economics. New York: Macmillan.

McCahill, C., \& Garrick, N. (2012). Automobile use and land consumption: Empirical evidence from 12 cities. Urban Design International, 17(3), 221-227. https://doi.org/10.1057/udi.2012.12

McDonnell, S., Madar, J., \& Been, V. (2011). Minimum parking requirements and housing affordability in New York City. Housing Policy Debate, 21(1), 45-68. https://doi.org/10.1080/10511482 .2011 .534386

Melo, P. C., Graham, D. J., \& Noland, R. B. (2009). A meta-analysis of estimates of urban agglomeration economies. Regional Science and Urban Economics, 39(3), 332-342. https://doi.org/10.1016/j. regsciurbeco.2008.12.002

Ogawa, H., \& Fujita, M. (1980). Equilibrium land-use patterns in a nonmonocentric city. Journal of Regional Science, 20(4), 455-475.

Osman, T. (2020). Land-use regulations and the dispersion of the IT industry in the San Francisco Bay area. Papers in Regional Science, 99(5), 1301-1316. https://doi.org/10.1111/pirs.12532

Rosenthal, S. S., \& Strange, W. C. (2003). Geography, industrial organization, and agglomeration. The Review of Economics and Statistics, 85(2), 377-393. https://doi.org/10.1162/003465303765299882

Rosenthal, S. S., \& Strange, W. C. (2004). Evidence on the nature and sources of agglomeration economies. In J. V. Henderson \& J.-F. Thisse (Eds.), Handbook of regional and urban economics (Vol. 4, pp. 2119-2171). Amsterdam: Elsevier. Retrieved from https://doi.org/10.1016/S15740080(04)80006-3

Rosenthal, S. S., \& Strange, W. C. (2010). Small establishments/big effects: Agglomeration, industrial organization and entrepreneurship. In Agglomeration economics (pp. 277-302). Chicago: University of Chicago Press.

San Jose Mercury News. (2019, March 12). Editorial: Why San Jose should raise downtown building height limits. San Jose Mercury News. Retrieved from https://www.mercurynews.com/editorial-whysan-jose-council-should-approve-raising-downtown-building-heights

Scharnhorst, E. (2018). Quantified parking: Comprehensive parking inventories for five U.S. cities [Research Institute for Housing America special report]. Washington, DC: Mortgage Bankers Association. https://www.mba.org/Documents/18806_Research_RIHA_Parking_Report\%20(1).pdf

Schmitt, A. (2013, June 17). Parking crater prevention: Which cities are doing it right? Streetsblog USA. Retrieved from https://usa.streetsblog.org/2013/06/17/parking-crater-prevention-which-cities-aredoing-it-right/ 
Shoup, D. (2011). The high cost of free parking. New York: APA Planners Press.

Storper, M. (1997). The regional world: Territorial development in a global economy. New York: Guilford Press.

Weinberger, R., Seaman, M., \& Johnson, C. (2009). Residential off-street parking impacts on car ownership, vehicle miles traveled, and related carbon emissions: New York City case study. Transportation Research Record, 2118(1), 24-30. https://doi.org/10.3141/2118-04

Willson, R.W.(1995).Suburban parkingrequirements:A tacitpolicy forautomobileuseandsprawl.Journal of the American Planning Association, 61(1), 29-42. https://doi.org/10.1080/01944369508975617 